\title{
León Rozitchner: fenomenología de una experiencia judía entre Freud y Marx ${ }^{1}$
}

\author{
León Rozitchner: Phenomenology of a Jewish Experience between Freud and Marx
}

Michael Maidan

michael.maidan@gmail.com

LAJSA (Latin American Jewish Studies)

\section{Resumen}

Este artículo explora el rol de la experiencia judía en el pensamiento del filósofo e intelectual de izquierda judeo-argentino León Rozitchner (1924-2011). Tomando como punto de partida su libro Ser Judío (1967), la interpretación que Rozitchner hace del judaísmo es analizada en sus escritos sobre san Agustín y sus últimos escritos de la década de los años 2000. Rechazando la interpretación del cristianismo como mera ideología que refleja en forma distorsionada el modo de producción social, Rozitchner elabora en sus últimas obras la idea que el cristianismo es la matriz y condición de posibilidad de la sociedad capitalista, y que su oposición al judaísmo no puede ser otra que una animosidad fundamental de la que la shoah no es una excepción aberrante sino su manifestación más ejemplar.

Palabras Clave: León Rozitchner; intelectuales judíos en Argentina; identidad judía; comunidad judía en Argentina; Marx; Freud; Cristianismo y capitalismo

\section{Abstract}

This paper explores the role of Jewish experience in the thought of the philosopher and JewishArgentine left-wing intellectual León Rozitchner (1924-2011). Taking as a starting point his book Ser Judio (1967), Rozitchner's intepretation of Judaism is analyzed in his writings on St.

\footnotetext{
${ }^{1}$ Una versión anterior de este trabajado fue presentado en el congreso anual de la Latin American Jewish Studies Association (LAJSA), Miami, Florida, 21-23 de Junio 2015.
} 
Augustine and in his later writings of the early 2000s. Rejecting the interpretation of Christianity as mere ideology reflecting in a distorted way the capitalist mode of social production , Rozitchner elaborates in his later works the idea that Christianity is the presupposition of capitalist society, and that Christianity's relationship to Judaism can not be other than a fundamental animosity of which the Shoah is not an aberration but its most exemplary manifestation.

Keywords: León Rozitchner; Jewish identity; Jewish intellectuals in Argentina; Argentine Jewry; Marx; Freud; Christianity and Capitalism;

¿Que pienso cuando uno, judío que no habla idish ni lo escribe, aunque lo comprende, sin embargo, siente que desde él ha penetrado en la lengua en la que nos expresamos, en este caso, el castellano? Es difícil describir ese 'no se qué' inasible, pero hay que pensarse hasta bien adentro para tratar de saberlo, porque allí reside, creo, su secreto. Más aún todavía: creo que solo puedo decirme y escribir en serio cuando habilito las primeras cadencias que me hablaban desde niño en idish, aunque yo no pueda hablarlo. Esto es lo que me deslumbra: el idish habla en mi de una manera extraña, aunque yo no hable.

Pensar en idish, Rozitchner (2015e:117)

La paradoja que Rozitchner evoca, la experiencia de un no-saber que constituye de todas formas nuestro ser, de un desconocer que subterráneamente y que a pesar nuestro habla por debajo de las formas explícitas de nuestro lenguaje, de un 'no se qué' que nos constituye, y que sin embargo requiere que lo "habilitemos", que lo hagamos explícito y conciente, pero también que lo rehabilitemos, sintetiza no solo la interpretación que Rozitchner hace de su judaísmo, sino uno de los modelos centrales de su pensamiento filosófico. A contracorriente de una concepción tradicional de la filosofía, que despliega el sentido de la pregunta "que es el hombre" como la Cuadernos Judaicos - ISSN: 0718-8749 
síntesis de una serie de preguntas preliminares: ¿qué puedo saber?, ¿qué debo hacer?, ¿qué me esta permitido esperar?, Rozitchner sostiene que la verdadera pregunta no es "¿que es el hombre?, sino “¿quien es el hombre?”, ¿quién es este hombre que soy yo? ${ }^{2} \mathrm{Y}$ al poner en el centro del pensamiento el absoluto-relativo que somos cada uno de nosotros, pone al mismo tiempo el problema del origen y del proceso por el cual devenimos lo que somos. Y como este origen no es otro que el propio, no podía dejar de ser, en el caso de Rozitchner, sino el suyo propio, judío-argentino, filósofo y militante.

Esta certeza paradojal, que aflora con claridad especialmente en sus ultimas obras, madura a lo largo de un proceso que la muerte interrumpió en 2011, y que la publicación póstuma de algunos de sus textos inéditos permite ver con más detalle. Esta experiencia, para no usar la palabra identidad, en la que él percibía una intromisión autoritaria y policial (Rozitchner, 2015e: 35), es compleja y contradictoria. No se trata en este trabajo de reducirla a sus condiciones de origen histórico-sociales, ni de darle artificialmente una unidad que no tiene, sino de describir su presencia y su función en el pensamiento de unos de los intelectuales aArgentinos más originales de mediados del siglo XX.

El siglo XX contó con numerosos filósofos de origen judío, pero contados aquellos que hicieron explícitamente de su judaísmo un elemento interno a su obra. Y aún estos, en su mayoría (Herman Cohen, Rosenzweig o Levinas por ejemplo) diferenciaban escrupulosamente entre un discurso confesional donde se tematizaría lo judío, de un discurso propiamente filosófico y universal. Rozitchner rechaza esta dualidad, que prolonga la distinción mendelssohniana entre lo privado y lo público, lo confesional versus lo filosófico. Como veremos, el pensamiento de Rozitchner se guía por la convicción contraria, es decir, que lo filosófico y lo político son lo personal. En este pensamiento que se define como un pensamiento del sujeto y del origen, el tema judío juega un rol central, que obedece a una dinámica interna y al movimiento propio de su reflexión. No es una mera reacción a un impulso de origen externo ni seducción de una moda

\footnotetext{
${ }^{2}$ Rozitchner, 2015a, p. 37. Cf. también Rozitchner,1996, p. 189. Encontramos la misma idea en su crítica al pensamiento de Levinas: "Si no ahondé hasta el extremo el sentido de lo excepcional y misterioso de mi propia vida, y no asumí desde allí la más profunda muerte que me espera, no podre nunca sentir qué es un semejante diferente". Rozitchner (2013), 182. Ver también C. Sucksdorf (2015), 38. 
pasajera. En ese sentido, se trata de un fenómeno singular y relativamente inusual para su generación.

León Rozitchner (1924-2011) es poco conocido fuera de su país, aunque su obra tuvo y posiblemente tendrá en el futuro influencia en el pensamiento de la izquierda argentina y en general, por sus originales intentos de combinar el pensamiento de Marx y Freud, y de inscribir el problema del sujeto en el pensamiento social progresista ${ }^{3}$. En la calle judía, Rozitchner es conocido sobre todo por su libro Ser Judío, publicado por primera vez en 1967, y re-editado en varias ocasiones, y por sus severas críticas al Estado de Israel luego de los conflictos en Líbano y en la franja de Gaza. En la calle "gentil" es conocido sobre todo por su rol en la revista Contorno (1953-1958), por su actividad como intelectual y pensador original ejercida sobre todo fuera del ámbito del claustro universitario y ocasionalmente en forma clandestina, y por las polémicas que lo opusieron a William Cooke, (ideólogo del acercamiento entre la izquierda y el peronismo), a Conrado Eggers Lan (un representante temprano de la teología de la liberación), a un grupo de intelectuales argentinos en el exilio que en 1982 apoyaron la acción militar argentina en Las Malvinas, por su rechazo a la influencia — que el consideraba nefasta- de Althuser y Lacan en la izquierda argentina, y por su rechazo de la postura de Oscar del Barco en la polémica sobre la violencia y la izquierda ${ }^{4}$.

\section{Itinerario:}

La edición de las obras de León Rozitchner publicada por la Biblioteca Nacional Argentina incluye en cada uno de sus volúmenes un itinerario de su pensamiento, que los editores dividen en cuatro periodos. En el primero, la investigación está orientada a la constitución del 'sentido' sobre la base de la vivencia de un mundo compartido con otros hombres. La filosofía busca determinar las experiencias "fundantes" — es decir, que sirven de cimiento — al sistema de

\footnotetext{
${ }^{3}$ Para un estudio sucinto del desarrollo del pensamiento de León Rozitchner, cf. Bosteels (2015).

${ }^{4}$ No vamos a desarrollar este tema en el presente trabajo, ya que por su complejidad requeriría un espacio mucho mayor. Baste que con mencionar que esta polémica tiene múltiples aspectos judíos. de los que Rozitchner está plenamente conciente. Del Barco basa su crítica al amoralismo del que acusa a la izquierda en el periodo de los años 60 y 70 en el pensamiento del pensador Emmanuel Levinas, conocido por integrar una óptica judía en su pensamiento. Muchos de aquellos que reaccionaron a su acusación tomaron posición a favor o en contra del pensamiento de Levinas, creándose una amalgama entre debate histórico-político, y debate filosófico. Para una introducción al debate, ver Tocho (2009).

Cuadernos Judaicos - ISSN: 0718-8749

No33 Diciembre 2016215
} 
símbolos abstractos, al lenguaje, y la cultura en general. Los problemas y la orientación son de tipo fenomenológico, en el espíritu de la obra de Merleau Ponty, pero con una apertura temprana a la obra de Marx y de Freud. A este periodo pertenecen su libro sobre Max Scheler —adaptado de su tesis doctoral en la Sorbona- y Moral burguesa y revolución, una meditación sobre la moral y la política a partir de las actas del juicio a los combatientes anticastristas apresados luego del fracasado intento de invasión en 1961.

En el segundo periodo se acentúa la lectura freudiana, sobre cuya base Rozitchner apunta a entender lo colectivo a partir de la forma en la que el Otro está presente en mi propio ser. Lo colectivo es estudiado sobre todo en sus formas patológicas y autoritarias en una serie de volúmenes publicados bajo la dictadura militar en Argentina y durante el periodo de su exilio en Venezuela: Freud y los limites del individualismo burgués (1972), Freud y el problema del poder (1982), Perón entre la sangre y el tiempo (1985).

El tercer período, que corresponde al re-establecimiento de la democracia en Argentina, coincide con la escritura de La Cosa y la Cruz (1997), libro que explora los orígenes del cristianismo y su rol como matriz de un modelo de tránsito de la naturaleza a la cultura basado en la negación radical de la experiencia arcaica materna. El cuarto está compuesto por textos escritos en los últimos años de su vida, en los que Rozitchner profundiza la tesis presentada en el libro sobre Agustín que la negación cristiana de la experiencia arcaica maternal como fundamento subjetivo de la sociedad capitalista. El texto clave de este periodo, que culmina con su muerte, es un texto del 2008, titulado en forma traviesa La mater del materialismo histórico ${ }^{5}$.

A esta periodización queremos superponer un plano adicional, en el cual aparecen otros desarrollos cuya relación con los anteriores vamos a tratar de explicar. Encontramos en primer lugar la irrupción de la cuestión judía en un texto de 1967 (Ser Judio), para entrar en un periodo de latencia, interrumpido por la publicación del libro sobre Agustín, texto en el cual lo judío aparece explícitamente como aquello que habilita y garantiza la lectura crítica de la obra de Agustín y del cristianismo en general. Este punto de vista es luego problematizado en una serie

\footnotetext{
${ }^{5}$ Christian Sucksdorf y Diego Sztulwark (2012: 9-13). Este texto se repite en todos los volúmenes de la edición de la BN.

Cuadernos Judaicos - ISSN: 0718-8749

No33 Diciembre $2016 \quad 215$
} 
de estudios en su mayor parte inéditos, y por lo tanto, tentativos, que constituyen buena parte del cuarto período mencionado. En estos, sin desaparecer totalmente del plano teórico, lo judío ya no aparece como índice privilegiado de inteligibilidad, y en es remplazado por la relación con la mujer/madre. Rozitchner explica esta transición en una nota, probablemente agregada durante una relectura: "Antes yo había escrito que mientras que exista la negación del otro por el hecho de serlo, la inhumanidad de los humanos, del anti-judaísmo, esa sería la prueba de que la revolución comunista era una revolución limitada a lo económico-político. Pero ahora tengo que afirmar que esa prueba pasa por la negación del otra puesta en lo femenino" (Rozitchner, 2013, p. 31 nota 1$)$.

\section{Ser Judío:}

Rozitchner escribe Ser Judío entre agosto y octubre de 1967, es decir, poco tiempo después de la guerra de los seis días, y como reacción a la ola de condenas a Israel por parte de los partidos comunistas y de los movimientos de izquierda y progresistas de América Latina y el Tercer Mundo. En un reportaje fílmico realizado por Diego Sztulwark (2015) poco tiempo antes de la muerte de Rozitchner y puesto en línea recientemente, Rozitchner recordaba el contexto que lo llevó a escribir este texto, especialmente en el seno de la izquierda, como un "clima de exterminio". Este sentimiento no es expresado sólo como constatación abstracta, sino en forma individualizada y altamente emocional, como podemos constatar en el comienzo de la sección II, donde Rozitchner habla explícitamente de antisemitismo en Argentina, en un contexto donde la referencia es claramente la izquierda:

Pasará, está pasando, pasó que se me reduce, se me achique, se me restringe a ir, mera biología, a la triste geografía de mi simple cuerpo sin tierra...me mueven el piso...pero más aún, me lo sacan...Esta negación está siempre presente para el judío como posible. Y hay que tener el coraje de aceptarla (Rozitchner, 2015e, p. 40).

El párrafo, que comienza con una referencia al pasado, presente y futuro, repetida tres veces en los párrafos precedentes como una aliteración siniestra, termina con una nota casi resignada. 
En paralelo con el contexto histórico de la guerra de los seis días, el conflicto árabe-israelí y las divisiones de la izquierda y los movimientos progresistas, podemos leer este libro también como un hito en el desarrollo del pensamiento de Rozitchner. No es casual que la escritura de este texto coincida con la publicación de su ensayo "La izquierda sin sujeto" (1966), quizás uno de los escritos mas emblemáticos de Rozitchner. Se puede poner estos dos textos en paralelo, y ver a Ser Judío como una aplicación concreta de lo que Rozitchner descubre en "La izquierda sin sujeto", e inversamente, interpretar "La Izquierda sin sujeto:" a la luz de Ser Judío. En un texto reciente, Bruno Boostels se refiere a Ser Judío como una crítica a un modelo de cambio y transformación individual y colectivo influenciado por el modelo cristiano de conversión, cambio, sacrificio y abnegación (Boostels, 2012, p. 118). Estos son justamente los temas de la discusión en "La izquierda sin sujeto". Ser Judio no es un texto que debamos encapsular solo en una problemática identitaria, o una respuesta puntual a una situación determinada y específica, sino que se engarza naturalmente con el tema del sujeto y su transformación que preocupa a Rozitchner en este período y que será uno de sus aportes más importantes al pensamiento progresista.

Ser Judío comienza con una exposición de lemas de una cierta vulgata marxista: debemos sacrificar lo Judío que se opone a la revolución. Pero antes de sacrificarlo, ¿no deberíamos ver qué es eso que se nos pide y que aceptamos sacrificar? Aquí descubre Rozitchner una evidencia fundamental: aún si hiciera él la prueba de deshacerse de todo lo que pudiera tener en común con los otros judíos, quedaría intacto el hecho de ser ese su "índice de tránsito", aquello a partir de lo cual decide su futuro como pensador de izquierda (Rozitchner, 2015e, p. 25-26). Este "índice de tránsito" es para Rozitchner, un "índice de inhumanidad de lo humano" (op. cit., p. 26). Es este índice que le permite reunir en una "unidad no contradictoria la común verdad de mi ser argentino con la de mi ser judío" (p., 26). Es a partir de su pertenencia a un grupo cuyo común denominador es haber sido perseguido por el solo hecho de existir, que Rozitchner encuentra una comunidad con todos aquellos que han sido y siguen siendo perseguidos y explotados: "Hay una coherencia en el mal del mundo, hay un vínculo entre dolor y dolor, hay una internacional del sufrimiento que viene al hombre por mano del hombre" (p. 27). Pero esta coherencia no es una mera identidad abstracta. La negación del judío se parece más a la negación del negro que a la negación del obrero ( p. 34), en cuanto se trata de una negación "por el hecho de ser". Es esta 
experiencia "que en todo judío, por el hecho de su origen, se abrió para él como un enigma, como una injusticia fundamental” (p. 34). Esta negación, sin ser toda la negación del mundo, ni necesariamente la mas profunda, "es la nuestra...es nuestro punto de inserción más radical en la historia del hombre, el punto nodal de toda nuestra comprensión" (p. 35). Y si abandonamos sin más este índice, entonces el sentido que nos lleva a asumir esta posición política de izquierda no se apoya realmente en una experiencia próxima, sino en una forma abstracta que Rozitchner caracteriza como un proceso anónimo, sin sujeto ni densidad (p. 35). Es decir,

porque si salimos de ser judíos para ser militantes, en algún momento abandonamos ese ser primero. Pero este abandono sin más, sin comprensión de lo que en nosotros se hizo...significa hacer abandono de la propia historia personal -la que me hizo surgir a mi dentro de la experiencia de ser-judio en algún momento de mi vida-como índice a mantener de ese tránsito hacia la toma de posiciones de izquierda. Y este abandono es posible porque se rechaza a lo propio judio en lo que tiene de positivo, a la emergencia contradictoria en uno mismo de lo que de judio hemos sido hechos, y se le asigna, a todo ese contenido...un sentido globalmente negativo (p. 33)

Rozitchner crítica esta negación no solo en el judío de izquierda. También el judío burgués hace caso omiso de la negación y se convierte en aliado del poder establecido, por lo menos todo el tiempo que la burguesía así se lo permita (p. 37). Pero sus palabras más duras están dirigidas al judío de izquierda, a sus propios compañeros de ruta, a los que advierte de la naturaleza ambigua de su sacrificio. Sin duda lo judío desaparecerá un día, cuando todo lo negativo desaparezca de la faz de la tierra, pero no antes. Sacrificar este índice prematuramente implica perder lo que tenemos de positivo, "porque no somos judíos sino por lo que tenemos de negativo" (p.37).

Ese ser judío que nos presenta Rozitchner no es la positividad de una cultura viviente. Hijo de la segunda generación de inmigrantes, la cultura judía que Rozitchner conoció "nunca [la] bebí sola, y eso en los primeros años, y sin pasión” (p. 25). En esto no se diferencia de muchos otros en su generación. Pero tampoco es la mera negatividad impuesta desde afuera por el opresor 
como la tematizó Sartre ${ }^{6}$, y de la que convendría entonces deshacerse cuanto antes. Es menos que la primera y mucho más que la segunda.

Hacia finales del libro va a aparecer una caracterización diferente de lo judío, ya no solo como índice, sino como necesidad de un tránsito, de la tierra prometida mesiánica y celestial a la realidad material en la cual viven los judíos concretos, ya sea en Argentina o en Israel: "No hay mas disyuntiva que ésta, o quedarse, y entonces asumir como todos los judíos de izquierda, esta realidad nacional...o irse, y asumir con los judíos israelíes de izquierda la realidad nacional de Israel, que pasará así de fantasía a realidad plena” (p. 86).

\section{Judaísmo, Cristianismo y Capitalismo:}

Entre la publicación de Ser Judio y la publicación de La Cosa y la Cruz, Cristianismo y Capitalismo (En torno a las Confesiones de San Agustín) transcurrieron 29 años, entre los cuales 10 de destierro en Venezuela, tres libros sobre la naturaleza del populismo peronista a partir de las enseñanzas de Freud, la muerte y el exilio de muchos amigos y compañeros de ruta. La Cosa y la Cruz es un libro que tiene un largo y pesado pasado. Se trata de un libro polémico, mal recibido cuando no ignorado por la academia oficial. El desafío y la provocación aparecen ya en las primeras páginas, que abren con esta afirmación: “¿Por qué las Confesiones de san Agustín cristiano interpretadas por un judio incrédulo? Primero, porque después de 16 siglos la deuda del cristianismo con la persecución y el genocidio de los judios no ha sido saldada” (Rozitchner, 1997, p. 9). A esto agrega otros dos puntos: a) el capitalismo no hubiera sido posible sin los presupuestos que se desarrollan en el Cristianismo a partir de Agustín; b) el fracaso de los "socialismos realmente existentes" es consecuencia de no haber modificado "aquello que la religión organizó en la profundidad de cada sujeto” (p. 9).

Rozitchner piensa la hostilidad del cristianismo hacia el judaísmo como necesaria y no contingente. En cuanto a las otras tesis, son quizás menos controversiales. La segunda tesis, es una reformulación y profundización de la que Max Weber aplicaba al Protestantismo, y tiene un

6 “el carácter judío no provoca el antisemitismo, sino que, a la inversa, es el antisemita quien crea al judío". Sartre (1960), p. 131.

Cuadernos Judaicos - ISSN: 0718-8749

No 33 Diciembre $2016 \quad 215$ 
pedigrí académico considerable. En cuanto a la tercera, se trata de como una reafirmación de la tesis original de "La izquierda sin sujeto", enriquecida por la experiencia política de la represión bajo el régimen militar y la experiencia reciente del derrumbe de los regímenes socialistas en el este de Europa.

Para Rozitchner, la obra de Agustín es el paradigma de una forma de subjetividad que el Cristianismo desarrolla; las Confesiones, a cuyo estudio dedica Rozitchner este texto, son un documento que atestigua del desarrollo de esta subjetividad en Agustín y eventualmente en la Iglesia. Por eso Rozitchner se desinteresa de otros aspectos de la vida y obra de Agustín (16). Lo que le interesa es como esta forma subjetiva prepara 'los mecanismos de la ciencia para “conocer" y dominar a la naturaleza' (17), culminando en la razón técnica, en el productivismo infinito del capitalismo' (18).

Lo judío aparece en La Cosa y la Cruz sobre todo como un elemento de comparación. Por ejemplo, este párrafo: "Los judíos mantenían el tránsito y la permanencia de la madre arcaica...el Cristianismo, en cambio, ha desmaterializado la vida...ha matado el cuerpo de la madre” (p. 148). Y más adelante, "en el cogito judío no puedo decir 'pienso en Dios luego yo existo'... lo hago existir en mi conciencia y en mi cuerpo afectivo...en cambio en el cristianismo pasa otra cosa" (p. 186). Y por fin: "El edén no era para los hombres, habia que pasar del principio soñado del placer eterno a la realidad despierta de la vida cotidiana. Dios nos arroja del Paraíso para que seamos hombres y no dioses. El cristianismo, en cambio, en un movimiento y de pavor...nos promete que hemos de volver al Paraíso..." (p. 200). Rozitchner no se interesa por lo que Agustín hubiera enseñado concretamente sobre los judíos, en parte porque su argumento se basa casi estrictamente en un "close reading" minucioso de Las Confesiones, y en parte por la función retórica que cumple el judaísmo en este debate como elemento de comparación y contraste. Declarándose judío, Rozitchner asume un punto de vista externo a la cultura occidental y cristiana cuyas raíces procura exponer en su lectura de la obra de Agustín.

\section{Pablo y los orígenes del Cristianismo:}


La Cosa y la Cruz se adelanta en algunos años a un singular interés de sectores de la izquierda europea por la fundación y el desarrollo del Cristianismo. Se trata de un fenómeno complejo, que obedece, a las decepciones provocadas por el derrumbe de los regímenes socialistas en Rusia y en Europa Oriental, y a la necesidad de repensar el destino de las luchas sociales emancipatorias. Giorgio Agamben, Alain Badiou, Toni Negri y Slavoj Žižek entre otros tomaron esa ruta. Los cuatro reflexionan, cada uno a su manera y estilo, sobre la figura del apóstol Pablo de Tarso. Estos pensadores se enfrentan además en grados diferentes a otra corriente de pensamiento que se presenta como alternativa al ideario progresista tradicional. Esta corriente, que revindica una inspiración judía, se reclama de la obra del filósofo Emanuel Levinas, y se caracteriza sobre todo por una concepción afirmativa de la idea de derechos humanos, y una reivindicación de la ética frente a la política y la filosofía.

Los escritos de Rozitchner reunidos en Cuestiones cristianas son contemporáneos de estas reflexiones, pero responden a un interés y un punto de vista diferente. Mientras que para los pensadores europeos se trata de re-examinar a la luz de los orígenes del Cristianismo la posibilidad de una renovación del impulso revolucionario, para Rozitchner se trata, por el contrario, de profundizar lo que el estudio de Agustín había puesto de manifiesto, es decir, el rol del cristianismo como matriz subjetiva de la modernidad capitalista. El "paulinismo de izquierda" revindica el "acontecimiento" simbolizado por la visión de Pablo en el camino a Damasco. Rozitchner por su lado, describe una encrucijada en la historia de la formación de la cultura occidental: por un lado los judíos que reaccionan a la destrucción del Templo y de su otrora vida nacional codificándola como judaísmo rabínico y reforzando la trascendencia de la ley patriarcal y por el otro, la vía paulino-cristiana, que subvierte la trascendencia en una falsa inmanencia:

la que Cristo trae, volviendo a la lengua originaria [es decir, previa a la destrucción de la torre de Babel] pero transformada en la lengua de un Dios-padre abstracto que da como cierta a la que Jehová había rechazado como peligrosa, solo que abriendo como un nuevo horizonte que parte del deseo de alcanzar el cielo como si ese cielo, al que no llegaron, apareciera de pronto como realizado. Como si la palabra materna que estaba en el origen viniera ahora desde el cielo, ese cielo al que apuntaban antes sin haberlo logrado. Se deja 
de lado el trabajo colectivo adulto de construir con ladrillos de tierra el Cielo [es la vía judía]. Como si, siendo ya adultos, volvieran a nuevo a ser niños (p. 81).

El cristianismo nos condena a ser simplemente niños en forma alucinada, en vez de permitirnos ser niños adultos, adultos que recuperan y subliman el niño originario en nuestra forma ahora de adultos. Entre estas alternativas, Rozitchner sigue valorizando en forma relativa la vía judía, a pesar de todas sus ambigüedades. Valoriza la "ineficacia de la solución judía”, la afirmación de la naturaleza absoluta de la ley, que salvaguarda la posibilidad de "enfrentamientos, desafíos, caídas, incumplimientos", que deja espacio para la discusión, y para desarrollar la verdad en la lógica contradictoria de los hombres y de sus perspectivas (35). La solución cristiana, que aparentemente interioriza la ley, no la humaniza. Es paradojalmente la solución judía, que coloca el máximo de distancia con la ley, que hace de esta la revelación de un dios absolutamente trascendente y hasta irrepresentable figurativamente, la que se abre a la práctica humana y prefigura una verdadera solución post-patriarcal al mismo tiempo que post-capitalista.

Rozitchner no ahonda en cual podría ser esta solución, pero podemos encontrar algunas indicaciones en una sección que dedicada ostensiblemente a la interpretación freudiana del cristianismo en Moisés y la religión monoteista. Rozitchner compara a Freud y a Pablo. Ambos son sectarios judíos, judíos heréticos que se deprenden del judaísmo, que reconocen la necesidad de universalizarlo y expandirlo en el mundo (44), y que tienen en común una serie de características exteriores quasi-eclesiásticas. Pero a diferencia de la religión, el psicoanálisis abre un espacio de debate donde se elucidar el drama de origen. Pero lo hace en forma limitada, ya que el psicoanálisis se restringió al campo de la terapia individual y al campo de las relaciones científicas, mientras que en el campo social, es el fracaso de los socialismos (¿otra herejía judía?) lo que muestra la falta de extensión de lo elaborado en el psicoanálisis (45). Psicoanálisis y marxismo, originalmente intentos de conceptualizar y abolir lo que en el desarrollo de la cultura devienen obstáculo para el desarrollo del ser humano se revelan como parte del problema. Se requiere, intuye Rozitchner, radicalizar la búsqueda, ir más allá del cristianismo, más allá mismo que el judaísmo, al origen de los orígenes.

\section{La Génesis del génesis:}

Cuadernos Judaicos - ISSN: 0718-8749

No33 Diciembre $2016 \quad 215$ 
"[Jean-Joseph] Goux parte de Moisés igual que lo hace Freud, pero debería haberlo hecho desde el Génesis" (2015c, p. 116), nota Rozitchner en Génesis. Buscar el origen en el Génesis quiere decir que la ley que Moisés entrega en Sinaí tiene que estar ya prefigurada en una primera ley, que es la que aparece en la creación del hombre y la mujer, el pecado original, y la expulsión del paraíso.

La óptica desde la cual se produce este análisis regresivo es una óptica judía, en la medida que quien la hace se proclama como tal, y también procura mostrar que estas experiencias fundamentales que habrían dado origen a nuestra civilización occidental y judeo-cristiana no son una experiencia única, sino que se especifican en direcciones que no son conciliables. Hay algo en el judaísmo que resiste su inclusión en el cristianismo/capitalismo. Rozitchner rechaza una dialéctica al estilo de Hegel que subsume completamente la verdad del judaísmo en el cristianismo. Tampoco asiente a la idea que una verdad esencial compartida, un judeocristianismo, como pretendieron algunos pensadores. Para Rozitchner, la verdad del cristianismo es el genocidio del judaísmo, porque el judaísmo preserva aún a pesar suyo y aun ignorándolo, un secreto que es un peligro mortal para el Cristianismo. Por eso repite Rozitchner, el holocausto es la "verdad material", es decir, no solamente contingente o histórica, del Cristianismo (p. 45).

Pero comenzar con el Génesis implica poner una distancia con lo judío. Anterior a la ley, el Génesis es presuntamente mito de origen universal, que precede al mito de origen del pueblo Judío. Pero el Génesis es también previo al éxodo, tema favorito de la teología de la liberación, corriente de pensamiento hacia la cual Rozitchner siempre se mostró reticente. Comenzar por el principio es matar entonces dos pájaros con una misma piedra.

Para examinar el mito de origen de las religiones abrahámicas, Rozitchner no propone partir de la oposición entre una "mirada alucinada", es decir, religiosa, y otra que sería "materialista y científica", sino entre tres formas alucinadas "que no terminan de acordarse" (p. 29). En el Génesis encontramos tres momentos. Un primer momento que sería el mundo de la inocencia. Un segundo que ya no es de inocencia pero que se sueña en el Paraíso (esta sería la forma judía). Por fin, un tercero que sería la experiencia cristiana. Rozitchner habla de estas tres formas como 
partes de un tríptico. Se trata de leer las imágenes del relato bíblico a partir de una experiencia arcaica, a partir del propio origen infantil y arcaico, pero al mismo tiempo desde una mirada adulta. Rozitchner supone que el narrador bíblico está reviviendo obscuramente su propia experiencia infantil. Por eso en el texto habría dos narradores, retomando en forma ingeniosa la teoría de un redactor Elohitico y otro Jawihsta. Rozitchner propone leer el Génesis como una poesía popular, que permite "que lo inconsciente se abriera paso a la razón pensante y la integrara" (40). "En la poesía bíblica” — Rozitchner se refiere al texto bíblico en general, no solo a sus secciones poéticas - "despuntaba el magma ya elaborado de la historicidad humana, ese que podría prolongarse en una racionalidad distinta a la cristiana” (p. 41). Y enfatiza, "el judaísmo" - el judaísmo, y no algunos judíos heréticos tradicionalmente invocados, como Spinoza, Marx y Freud- "abrió, y aun contradictoriamente planteó, el espacio de una sociabilidad nueva" (p. 46).

La primera sección del tríptico representa la fantasía de la inmediatez ("carne con su carne”) con la madre. Es la proyección de la infancia en el adulto. Es la creación desde el punto de vista del niño reavivada en la experiencia del escriba que como testigo participa con Dios de la creación. Imaginario infantil y realidad adulta coinciden. La creación se construye a partir de las imágenes que el niño ha vivido con el cuerpo de la madre. Pero, esta experiencia está proyectada en Dios, y no hay origen materno. Hombre y mujer son creados a imagen y semejanza de Dios, adultos, sin infancia, sin madre, pero también sin diferencia significativa.

La segunda sección del tríptico corresponde a la versión Jawhvista. Es la narración anterior, ahora enriquecida con lo que faltaba a aquella, es decir, la madre. Aquí la mujer no es creada junto al hombre a la imagen de Dios sino creada como diferente en el sueño del hombre. El Edén como sueño incluye la prohibición — representada en el texto bíblico como prohibición de comer el fruto prohibido que permite conocer el bien y el mal- del conocimiento inicial que obtenemos del cuerpo de nuestra madre, que nos enseña a tragar o a escupir, elementos primarios de todo conocimiento, la afirmación y la negación. En el Edén el hombre crea a la mujer en su sueño, "le nace desde lo más adentro de sí mismo", y por eso puede ser carne de su carne y hueso de su hueso; esta mujer es "la mismísima madre que...Elohim, al hacerlo nacer adulto, había ocultado" (p. 86). Esa es la primera unidad del hombre, no solo con sus ideas, sino con la 
materialidad del cuerpo unido en su origen al cuerpo de la madre. Pero, para mantener la unidad, hay que ignorar lo que está ocurriendo, ocultar que cada amor es amor incestuoso. Una vez que lo sabemos, se produce una división, entre el Paraíso que queda como paraíso perdido, que es el de la infancia, y el de la naturaleza ahora despojada de su poesía y convertida en objeto de trabajo. Es la solución judía tradicional, donde persiste la forma antropomórfica de la divinidad, y en donde la relación con el mundo que no esta desvalorizada, como en el cristianismo, sino solo acotada. Rozitchner resume así las tres miradas sobre el Génesis:

En el primer volet los dioses y las dioses vencidos fueron expulsados y borrados en el monoteísmo...En el segundo...[en] el Edén que Dios les abre como si volvieran a vivir en el cuerpo extendido de la madre...vuelve a aparecer la Ley limitando los sueños para que no conozcan el origen del Bien y del Mal verdadero...El tercer volet va a mostrarnos que de los dioses radiados en el monoteísmo que expresaría la final y definitiva verdad del hombre, no han podido aniquilar a la única Diosa a la que todo hombre vuelve siempre...El monoteísmo no ha podido vencer en el hombre a la única Diosa resistente, que delata la falsedad o al menos la densidad irreductible que no puede ser radiada para que el hombre sea verdaderamente hombre" (p. 91) ${ }^{7}$.

\section{La cuestión Judía - El descubrimiento y los límites del pensamiento de Marx}

El ensayo de Rozitchner sobre el artículo de Marx sobre la cuestión judía es un texto tardío, quizás uno de los últimos redactados y preparados para publicación por el autor mismo.

\footnotetext{
${ }^{7}$ En una serie de conferencias dictadas en 2006 y 2007 Rozitchner continua explorando la idea de formas radicalmente diferentes de acceso de la naturaleza a la cultura, es decir, que existe una diferencia cultural fundamental entre Judíos y Cristianos, o en otros términos, que hay "diferentes Edipos". Cf. Rozitchner (2015b), p. 155-176. Rozitchner considera que la interpretación lacaniana de Freud es una repetición del vaciamiento del judaísmo por el cristianismo. Las principales diferencias que Rozitchner señala son: 1) El mito colectivo judío se convierte en mito individual en el Cristianismo. Ya no se trata de la salvación de un pueblo, sino de un individuo. 2) El poder del padre antropomórfico (el Dios antropomórfico), que tiene un nombre propio es sustituido por el poder sagrado de un Dios padre abstracto. 3) Transformación de la madre de madre efectiva en madre-virgen, no una madre "fervorosa que todos hemos conocido en algún momento de nuestra primera parte de a vida". Por el contrario, es una madre rendida ya al poder político, que como Yocasta en la tragedia de Edipo, envía a su hijo a la muerte.
} 
Rozitchner se enfrenta en él a un texto transicional y problemático, en el cual el joven Marx prepara una serie de rupturas políticas y teóricas con sus posiciones anteriores ${ }^{8}$. Se trata de un texto que contiene en algunas de sus secciones un lenguaje ofensivo contra los judíos y el judaísmo, aunque al mismo tiempo Marx defiende los intereses de la comunidad judía alemana de su época, señalando sin embargo los límites de una integración meramente formal que deja intactas las estructuras sociales discriminatorias y opresivas de la sociedad. Son estos los puntos que recalca Rozitchner, pero lo más original de su interpretación es la forma en la que Rozitchner presenta a Marx como personalizando el problema. Rozitchner dice que Marx conoce en carne propia lo que Bauer presenta en forma abstracta:

Marx sabe lo que dice, puesto que ya habia vivido en carne propia ese doble tránsito que Bauer le pide al judío para ser ciudadano: cuando niño, nacido en familia judía de antigua tradición rabínica, él mismo fue convertido al cristianismo por su padre a los seis años. Entonces Marx ya hizo la experiencia de la primera fase. Su conocimiento es distinto al de Bauer, porque habiendo residido en el cristianismo luego de haber nacido judio -experiencia que Bauer no ha sufrido-y defraudado por lo que había perdido en ese tránsito, debe haber vuelto hacia su propio pasado -es imposible no pensarlo-para comprender la transacción que Bauer les exige a los judios. (Rozitchner, 2015d, 143)

La posición ilustrada de Bauer esconde en el fondo, interpreta Rozitchner, una perspectiva antisemita, un antecedente de la Shoah (p. 145). El otro punto original de la interpretación de Rozitchner consiste en señalar que cuando Marx habla de 'actividad egoísta judía', ligada al comercio y a la usura, lo que en realidad está poniendo de manifiesto es el rol que les toca a los judíos en la división espiritual del trabajo, en la parte que la sociedad cristiana asigna a los

\footnotetext{
${ }^{8}$ El texto de Marx sobre la cuestión judía es un comentario crítico a dos escritos de Bruno Bauer. Fue publicado por Marx en 1844, pero la censura confiscó la casi totalidad de los ejemplares de la revista en la que fue publicado, por lo que en realidad este texto no vio la luz hasta mucho más tarde. Más que un estudio de la "cuestión nacional", como fue interpretado posteriormente, o de crítica de la religión, se trata de un texto sobre el problema de la emancipación de las minorías judías en Alemania en la segunda mitad del siglo XIX, cuya demanda de derechos civiles Marx apoyó contra Bauer. Un año más tarde, Marx retoma su ataque a Bauer, y cita con aprobación la posición de algunos voceros de la comunidad judía reformista que critican a Bauer. Cf. Bensaïd (2011), p. 27. Ver también el análisis de Bruno Boostels (2013), pp. 40-46, que resitúa la contribución de Rozitchner en el contexto del "neo-paulinismo de izquierda".
} 
judíos, que así puede concebirse a si misma purificada: "Entonces los cristianos proclaman desde su Dios puro que el Dinero es el espurio Dios judío, puesto que ellos las declararon impuras a todas, como impura es toda la naturaleza e impuro el propio cuerpo" (p. 163; énfasis agregado).

Sobre esta base, entonces, Marx habla a los judíos para pedirles que rechacen la propuesta de Bauer, ya que lo que deben hacer es "desandar el camino histórico que los llevo hacia la esencia religiosa judía" para encontrar escondida, en su misma base, como si los esperara cuando se despiertan del sueño, la esencia humana genérica" (p. 117). Marx seria el heredero judío-laico, el verdadero maskil, "que pone de relieve los supuestos cristianos que han hecho posible la creación de la realidad empírica...del Estado democrático como la de los judíos europeos", mientras que la haskala de Mendelssohn no pudo crear, a partir de sus propias experiencias fundamentales, una racionalidad diferente a la cristiana. Y Marx, que habría vivido en su persona el fracaso de la asimilación, seria quien convierte esta experiencia íntima en una visión de la historia que recupera el sentido de la emancipación humana. “¿Por qué, si no, esta necesidad de plantear el problema religioso cuando el hombre busca en el Estado su liberación política?", pregunta Rozitchner. La respuesta tradicional a esta pregunta es, que Marx no dispone aún de una teoría de la historia y de la economía que le permita entender la génesis y el modo de funcionamiento del Estado. No es así para Rozitchner, ya que "dependerá de cómo ese misterio del conflicto entre judíos y cristianos se resuelva para que la liberación humana pueda ser pensada". Marx en 1844 pensaba que la crítica de la religión ya había sido completada en lo esencial, y que ahora solo restaba poner en practica esta crítica de un punto de vista político. Rozitchner comprueba, por el contrario, que "hay que volver de la alienación política a la religiosa para comprender la subsistencia de lo religioso en lo político" (p. 147).

La supervivencia de lo religioso en lo político asoma como escisión de la forma humana que aparecería simultáneamente como forma religiosa y como forma política, es decir, como individuo (burgués, miembro de la sociedad civil) y como ciudadano. Es la dualidad que Marx encuentra en la revolución francesa y en la declaración de los derechos "del hombre y del ciudadano". El estado moderno reproduce la dualidad que encontramos en el cristianismo, y en esta dualidad le cabe al judío un rol particularmente penoso, que lo confina al ámbito de la materia despreciable y pecaminosa, a la "necesidad humana despreciada". 
Bauer le pide al judío que deje de serlo. Parecería que Marx dice lo mismo. Pero Rozitchner señala una diferencia:

Bauer, que pide que el judio deje de ser judío, no ve entonces que su critica "cientifica” ilustrada se mantiene y reposa en su fundamento religioso. Marx transforma la pregunta de Bauer y la baja a la tierra: “¿cuál es el elemento social especifico que hay que vencer para superar al judaísmo?” Lo que implica reconocer necesariamente "la posición especial que ocupa el judaísmo -y el judio actual - en el mundo esclavizado de nuestros días”, que entonces no es igual a la de cualquier oprimido. Y es una tarea de la cual sólo el judío puede ocuparse cuando se trata de liberarse a si mismo. Pero de un judio que haya reconocido, como Marx lo hizo, el significado secreto del cristianismo en el propio judio. Lo sabe por experiencia propia (p. 160).

Y si no Marx, por lo menos Rozitchner, que hace "reverdecer" - para usar una expresión por él querida - el texto de Marx con su propio entusiasmo y salvia vital. ¿Cómo funciona esto en la práctica? La segunda parte del escrito de Marx ataca un ensayo de Bauer intitulado La capacidad de los judios y de los cristianos de hoy para llegar a ser libres. Esta es la sección donde se encuentran las declaraciones más ofensivas acerca de los judíos, y que Rozitchner nos advierte no deben ser leídas como si fueran acerca de los judíos-judíos, sino de los judíos-cristianizados, o de la sociedad cristiana en general. Donde Marx escribe: "la emancipación social del judío es la emancipación de la sociedad del judaísmo" (Marx, 2011, p. 90), Rozitchner glosa:

La emancipación del judio requiere que este se emancipe, como judio, pero primero de ese judaísmo en el que el cristianismo lo ha convertido en el judio-delcristianismo. Esa es la tarea también social de los judos en la sociedad cristiana. Deben deshacer la trampa cristiana de la sociedad que los somete, pero primero en sí mismos. El secreto de la persecución judía se revela en el análisis de la religión y de la burguesía cristiana: sirve para poner de relieve el fundamento del poder del Estado cristiano y capitalista. Por eso su emancipación tiene en los 
judios la clave histórica de esa metamorfosis: porque se realizó en ellos mismos. Marx a los 23 años, que sufrió ambas, y que esta actualizando quizás su propio derrotero, pudo pensarlo (p. 176).

Y a continuación cita la frase de Marx que ya hemos citado, y nos ofrece la interpretación siguiente:

por lo que hemos entendido del texto de Marx creemos que esta frase debería leerse como sigue: "la emancipación social del judio-judio es la emancipación de la sociedad del judaísmo cristiano" (p. 177).

El enunciado de Marx es anfibológico, reconoce Rozitchner, y bifronte. Si se lo mira desde el punto de vista ofuscado del cristiano y del judo-cristianizado, puede ser leído como una invitación a la persecución y al exterminio (efectivamente, jasí lo han leído muchos!). Pero si lo miramos con el ojo del judío descristianizado, el texto promete una perspectiva de emancipación. Pero aun si adoptamos una posición que acoge con simpatía el punto de vista del judíodescristianizado que propone Rozitchner, no está muy claro cuál es la perspectiva que abre esta declaración. Cuando Rozitchner habla de los “judíos-judíos”, está pensando en los judíos de antaño, esos que bien o mal combatían a griegos y romanos para defender su modo de vida y su cultura. Pero eso son los del pasado. Los nuevos “judíos-judíos” le parecen demasiado cristianos, demasiado dispuestos a formar parte del mundo occidental y cristiano, de las nuevas cruzadas. Con esos siente poco en común 9 .

Rozitchner concluye su ensayo con un referencia sobre la Shoah como límite de la inteligibilidad del marxismo convencional, y quizás de Marx mismo:

$9 \quad$ La tercera parte del ensayo de Rozitchner presenta una serie de reflexiones sobre la obra de Marx y su desarrollo. Estos análisis son continuación del ensayo 'Marx y la infancia' (Rozitchner, 2015d:21-97) y critican la incomprensión que muestra Marx del carácter constituyente del hecho religioso y del carácter fetichista, no solo de la mercancía como afirmaba aquel, sino del sujeto mismo. De esta sección solo recogemos la sección intitulada 'Diferencia entre un Dios y el otro. El Dios judío' (188-190) donde Rozitchner desarrolla la teoría de dos desplazamientos de la madre primordial. En el caso judío, este no llega a despojar a la naturaleza del aurea materna (cf. "La mater del materialismo histórico", Rozitchner, 2011). La madre es relegada pero no es substituida por una madre distinta, mientras el padre "conserva un relente material antropológico". "Por eso el Dios judío es trascendente, una distancia infinita y externa lo separa judío de cada judío", solo el pueblo es primogénito. Y el rol de la madre no es usurpado, sino solo desplazado. 
La teoría del reflejo para explicar lo religioso se ha convertido en el ecumenismo laico del ‘marxismo' político y filosófico. Hasta tal punto que desde la época cultural y política en que Marx escribe este trabajo, y mas aún pensando que no podía prever lo mas impresionante de su posterior desarrollo, la solución final de la 'la cuestión judía' culminó con el exterminio de millones de judíos, Los análisis teóricos del capitalismo, y sobre todo los análisis políticos, dejaron sin embargo de lado la feroz persistencia de la esencia cristiana en el capitalismo, como si esta no fuera la tecnología de dominio religioso sin la cual es imposible pensar la existencia del capitalismo. El problema que planteamos, nos damos cuenta entonces, resulta del hecho de que El Capital, siendo como es el análisis mas profundo y sutil que sobre el se haya hecho, no nos permite sin embargo comprender desde allí el exterminio judío como una necesidad de la esencia cristiana del capitalismo. Desde un capitalismo pensado solo como una contradicción de las relaciones productivas, sin el predominio activo de su esencia cristiana, no se entiende la 'solución final' que encontró la cuestión judía que Marx había planteado en Sobre la cuestión judía (p. 200201).

La incapacidad del marxismo de pensar, no ya la cuestión judía, sino especialmente la cuestión cristiana, es decir, la persistencia del cristianismo que funciona como precondición subjetiva del capitalismo, proviene de no hacer explícito lo que Marx, como después Freud, podría haber sabido como parte de su propia herencia judía, pero que Marx como Freud mas tarde prefieren pasar por alto.

\section{6. ¿Más allá de la cuestión judía?}

Aunque no abandonado en sus últimos escritos, el paradigma judío parece pasar a segundo plano, o al menos encontrar un serio rival, en la idea de una experiencia originaria pre-patriarcal ('materialismo ensoñado') directamente accesible sin la mediación de una cultura determinada. Esta experiencia, de la cual el concepto de 'ser genérico' del Marx joven habría sido una prefiguración, es lo que Rozitchner siente que necesita como cimiento para su filosofía crítica. 
Es su mito científico de origen y de llegada, base para una sociedad 'normal'10, es decir, una sociedad emancipada y post-fetichista.

Es posible que la noción de un pensamiento de izquierda que revindica una identidad judía se haya lentamente agotado de poder creativo, aunque Rozitchner jamás la abandone totalmente. Es concebible que consciente o inconscientemente se haya inclinado a dar más lugar a la mujer en su pensamiento, influenciado por el zeitgeist imperante. Y también es posible que le haya resultado cada vez más difícil conciliar su identidad como judío progresista con las realidades geopolíticas del conflicto mesoriental. Debió hacérsele cuesta arriba justificar su posición frente a amigos y enemigos, y el abanderamiento de Israel en la causa occidental y cristiana sin duda ofendió a su anti-norteamericanismo visceral ${ }^{11}$. Como a otros, le resultaba más fácil identificarse con su pueblo cuando éste era un despojo sufriente, y difícil reconocerse en un Estado que parece virar cada vez más hacia la derecha y hacer causa común con aquellos que el progresismo considera sus enemigos jurados. Algunos artículos republicados ahora en el volumen Ser Judío así lo muestran.

Habiendo partida en Ser Judío de una fenomenología de lo judío (“¿qué es lo que yo tengo de judío?”, “qqué es eso que se me pide que niegue?”), el discurso de Rozitchner corre el riesgo de convertirse en una metafísica. Lo judío, una categoría eterna ahora, se convierte en una esencia metafísica que encarna el rechazo al capitalismo y sus males, desde siempre, desde antes que hubiera capitalismo. Y cuando los judíos empíricos, en Israel o en la diáspora, no encarnan esa esencia metafísica, entonces el verbo se hace violento y flagelador contra esos judíos carnales que no se comportan según la esencia adscripta.

No importa que esto requiera desmontar al judaísmo realmente existente, como realidad cultural o como realidad social. Quizás por eso, un tanto despechado por ese pueblo al que tanto amó, en sus últimos escritos Rozitchner parece hacer lo que Freud mismo no hizo, es decir, desmontar el monoteísmo mismo, y sumarse a la hipótesis de la existencia de una forma politeísta-feminista primigenia que habría sido remplazada por una forma monoteísta-patriarcal que luego devendría

\footnotetext{
${ }^{10}$ En Marx y la Infancia Rozitchner especula sobre la afirmación de Marx que los griegos habrían sido un pueblo normal, ya que para ellos la infancia no habría estado en contradicción con la vida adulta. Rozitchner (2015d, 57)

${ }^{11}$ Ver el análisis de Alejandro Horowicz (2015), p. 196.

Cuadernos Judaicos - ISSN: 0718-8749

No 33 Diciembre 2016 
capitalista. Esto existe como tendencia en los escritos del último periodo. Y sin embargo, cuando remata su crítica a Marx, en el último texto preparado por el mismo para publicación, es, como ya lo hemos visto, invocando a la Shoah en su dimensión judía concreta y no en tanto que metonímico genérico de la barbarie, que le asesta el golpe de gracia.

\section{Bibliografía:}

Bensaïd, Daniel (2011) Zur Judenfrage: una crítica de la emancipación política, Esteban Vernik (comp.), Volver a la cuestión judía, Madrid: Gedisa Editorial

Bosteels, Bruno (2012) Marx and Freud in Latin America: Politics, Psychoanalysis, and Religion in Times of Terror. London: Verso.

Boostels, Bruno (2013) On the Christian Question, en: Costas Douzinas and Slavoj Zizek, The Idea of Communism, vol 2: Verso

Bosteels, Bruno (2015) La izquierda con sujeto, AAVV (2015), León Rozitchner: contra la servidumbre solitaria, Jornadas en la Biblioteca Nacional, Buenos Aires: Biblioteca Nacional

Horowicz, Alejandro (2015) Ser Judío en Marx, Ser Judío en Rozitchner, AAVV (2015), León Rozitchner: contra la servidumbre solitaria, Jornadas en la Biblioteca Nacional, Buenos Aires: Biblioteca Nacional

Rozitchner, Léon (1996) Las desventuras del sujeto político: Ensayos y errores, Buenos Aires: Ediciones El Cielo por asalto

Rozitchner, Léon (1997) La Cosa y la Cruz: Cristianismo y Capitalismo (En torno a las "Confesiones" de san Agustin, Buenos Aires: Editorial Losada 
Rozitchner, Léon (2011) Materialismo ensoñado: Ensayos, Buenos Aires: Tinta Limón

Rozitchner, Léon (2012) Filosofia y emancipación, Simón Rodríguez: el triunfo de un fracaso ejemplar, Buenos Aires: Biblioteca Nacional

Rozitchner, Léon (2013) Cuestiones cristianas, Buenos Aires: Biblioteca Nacional

Rozitchner, Léon (2013) Levinas o la filosofía de la consolación, Buenos Aires: Biblioteca Nacional

Rozitchner, Léon (2015a) Ensoñaciones, Buenos Aires: Biblioteca Nacional

Rozitchner, Léon (2015b) Escritos psicoanalíticos: matar al padre, matar al hijo, matar a la madre, Buenos Aires: Biblioteca Nacional

Rozitchner, Léon (2015c) Génesis: la plenitud de la materialidad histórica (y otras escrituras impias), Buenos Aires: Biblioteca Nacional

Rozitchner, Léon (2015d) Marx y la infancia, Buenos Aires: Biblioteca Nacional

Rozitchner, Léon (2015e) Ser Judio y otros ensayos afines, Buenos Aires: Biblioteca Nacional

Sartre, Jean-Paul (1960), Reflexiones sobre la cuestión judia, $2^{\mathrm{a}}$ edición, Buenos Aires: Sur

Sztulwark, Diego (2015), Es necesario ser arbitrario para hacer cualquier cosa: conversaciones de Diego Sztulwark con Léon Rozitchner, Cuarta conversación: “¿Se puede seguir siendo Judío? ¿se puede ser judio y de izquierda? http://anarquiacoronada.blogspot.com/2016/01/es-necesario-serarbitrario-para-hacer.html (acceso: 28.8.2015)

Sucksdorf, Christian y Diego Sztulwark (2012) Presentación, Léon Rozitchner, Filosofía y Emancipación, Buenos Aires: Biblioteca Nacional

Cuadernos Judaicos - ISSN: 0718-8749

No33 Diciembre $2016 \quad 215$ 
Sucksdorf, Cristian (2015) ¿Es Léon Rozitchner un filósofo argentino? AAVV (2015), León Rozitchner: contra la servidumbre solitaria, Jornadas en la Biblioteca Nacional, Buenos Aires: Biblioteca Nacional.

Tocho, Fernanda (2009) Defender la vida, ¿matar la revolución? Un debate sobre la responsabilidad de la izquierda revolucionaria en los '70. Reseña de : AA.VV, (2007) No matar. Sobre la responsabilidad. Córdoba, Ediciones La Intemperie- Ediciones del Cíclope- Editorial Universidad Nacional de Córdoba, 461 páginas, Sociohistorica, p. 193-197 (accesible en: http://www.scielo.org.ar/scielo.php?script=sci_arttext\&pid=S1852-16062009000100009) (accedido en 19/12/2016) 